\title{
ANALISIS EFEKTIVITAS GAS TURBINE GENERATOR DENGAN METODE OVERALL EQUIPMENT EFFECTIVENESS
}

\author{
Sayuti, M, Silvira Maulinda \\ Jurusan Teknik Industri, Fakultas Teknik, Universitas Malikussaleh Aceh \\ Email:sayuti_m@unimal.ac.id; silviramaulinda16@gmail.com
}

\begin{abstract}
Abstrak-Peningkatan efektifitas sangatlah penting bagi perusahaan untuk memperoleh keberhasilan pada proses usahanya. Salah satu contoh peningkatan efektivitas adalah dengan mengevaluasi kinerja fasilitas produksi pada perusahaan. PT. $X$ merupakan salah satu perusahaan industri kimia dasar dengan produksi utamanya adalah pupuk urea. Salah satu unit penunjang proses produksi adalah Gas Turbine Generator (GTG) di unit utility. Dalam mendukung proses produksi, GTG seringkali mengalami permasalahan yang secara langsung menghambat proses produksi. Penelitian ini bertujuan untuk menganalisis pengukuran efektivitas Gas Turbine Generator dengan menggunakan metode Overall Equipment Effectiveness (OEE). Hasil analisis menunjukkan bahwa Gas Turbin Generator tingkat efektivitas yang diperoleh adalah sebesar 68,39\% yang menunjukkan bahwa nilai efektivitasnya produksi dianggap wajar, tapi menunjukkan ada ruang yang besar untuk improvement.
\end{abstract}

Kata kunci: Efektivitas, Gas Turbine Generator, Overall Equipment Effectiveness

\begin{abstract}
Increasing effectiveness is very important for companies to obtain success in their business processes. One example of increasing effectiveness is by evaluating the performance of production facilities in the company. PT. $X$ is one of the chemical industry companies whose main production is urea fertilizer. One of the supporting processes of the production process is the Gas Turbine Generator (GTG) in the utility unit.In supporting the production process, GTG often experiences problems that directly hinder the production process. This study aims to analyze the effectiveness of Gas Turbine Generators by using the Overall Equipment Effectiveness (OEE) method. The results of the analysis show that the Turbine Gas Generator effectiveness level is $68.39 \%$ which indicates that the value of production effectiveness is considered reasonable, but shows there is a large space for improvement.
\end{abstract}

Keywords: Effectiveness, Gas Turbine Generator, Overall Equipment Effectiveness

\section{PENDAHULUAN}

Peningkatan efektifitas menjadi salah satu faktor penting dalam menunjang keberhasilan proses usaha suatu perusahaan. Salah satu langkah untuk meningkatkan efektivitas adalah dengan melakukan evaluasi rutin kinerja fasilitas produksi. Ketidaksiapan fasilitas produksi dalam menunjang proses produksi dapat mengakibatkan proses produksi mengalami hambatan atau mengalami kegagalan produksi. Perencanaan perbaikan atau pemeliharaan mesin yang baik dapat meminimalkan biaya yang tidak terduga yang berdampak pada kenaikan total biaya produksi. Pemeliharaan peralatan mencakup pada kegiatan perbaikan (repair), perkiraan (predictive), dan pemeriksaan menyeluruh (overhaul). Pengukuran kinerja peralatan harus mampu menunjukkan kinerja peralatan sesungguhnya dan dapat memberikan data yang dapat digunakan untuk perbaikan di masa mendatang. Salah satu metode yang biasa digunakan dalam mengukur kinerja peralatan adalah TPM (Total Productive Maintenance).

Total Productive Maintenance merupakan suatu sistem pemeliharaan dan perbaikan pada mesin atau peralatan yang melibatkan semua pihak yang berkepentingan dalam suatu perusahaan dari mulai operator sampai puncak manajemen berdasarkan komitmen yang telah disepakati. TPM menggabungkan beberapa ilmu tingkah laku (manusia dan mesin), rekayasa sistem, ekologi (perubahan mesin), dan logistik dalam menciptakan sistem perawatan yang terintegrasi(Nakajima, 1988) 
TPM dirancang meminimalkan kegagalan fungsi suatu peralatan selama proses produksi berlangsung untuk meminimalkan kerugian yang terjadi. Kerugian karena kegagalan fungsi peralatan disebabkan antara lain kecacatan produk karena kegagalan fungsi peralatan saat proses produksi dan kerugian karena kecepatan produksi tidak maksimal yang disebabkan performance alat tidak sesuai dengan yang telah direncanakan (Iswardi \& Sayuti, 2016).

PT. $X$ adalah salah satu perusahaan industri kimia dasar dengan produksi utamanya adalah pupuk urea. Berdasarkan informasi yang didapat dari departemen pengendalian proses dan energi, di unit utilitas pengukuran efektivitas peralatan Gas Turbine Generator mengalami kendala karena seringnya terjadi kerusakan sehingga mempengaruhi kinerja dari mesin tersebut. Permasalahan tersebut akan diteliti dengan menganalisis tingkat kinerja perawatan mesin dengan pendekatan pengukuran nilai kinerja TPM menggunakan metode Overall Equipment Effectiveness (OEE)dengan memperhatikan faktor dominan penyebab terjadinya masalah di bagian proses.

Tujuan penelitian ini adalah untuk mengetahui tingkat efektivitas peralatan Gas Turbin Generator dengan menggunakan metode Overall Equipment Effectiveness (OEE). Tingkat pengukuran ini bisa dijadikan dasar evaluasi perusahaan dalam meningkatkan

\section{METODE PENELITIAN}

Waktu penelitian dimulai pada bulan Maret dan April 2017. Sedangkan yang menjadi objek penelitian adalah mesin Gas Turbin Generator.Tahapan-tahapan dalam melakukan pengukuran efektivitas mesin Gas Turbin Generator dengan menggunakan metode Overall Equipment Effectiveness (OEE).

OEE memberikan metrik kuantitatif berdasarkan ketersediaan elemen, kinerja dan kualitas untuk mengukur efektivitas kinerja (Garza-Reyes, 2015; Jonsson \& Lesshammar, 1999; Singh, Shah, Gohil, \& Shah, 2013). Metrik kuantitatif ini dapat digunakan sebagai dasar evaluasi dan langkah untuk meningkatkan efektivitas penggunaan mesin dan peralatan.(Jannah, Supriyadi, \& Nalhadi, 2017). Kemampuan mengidentifikasikan secara jelas akar permasalahan dan faktor penyebabnya sehingga membuat usaha perbaikan menjadi terfokus merupakan faktor utama metode ini diaplikasikan secara menyeluruh oleh banyak perusahaan didunia (R.Almeanazel, 2010)

Perhitungan OEE dapat dilakukan dengan menggunakan formula:
Availability $x$ Perform. $x$ Quality Rate $x 100$ (1)

Tiga rasio utama dalam perhitungan OEE akan dijelaskan sebagai berikut:

a. Availability rate adalah suatu rasio yang menggambarkan pemanfaatan waktu yang tersedia untuk kegiatan operasi mesin atau peralatan(Gupta \& Garg, 2012). Adapun rumus untuk menghitung nilai availability adalah sebagai berikut:

$$
\frac{\text { Operating Time }}{\text { Loading Time }} \times 100 \%
$$

b. Performance rate merupakan suatu ratio yang menggambarkan kemampuan dari peralatan dalam menghasilkan barang. Rasio ini merupakan hasil dari operating speed rate dan net operating rate. Operating speed rate peralatan mengacu kepada perbedaan antara kecepatan ideal (berdasarkan desain peralatan) dan kecepatan operasi actual net operating rate mengukur pemeliharaan dari suatu kecepatan selama periode tertentu. Perhitungan nilai performance dapat dilakukan dengan menggunakan persamaan dibawah ini:

$$
\frac{\text { Jumlah unit yang diproduksi }}{\text { Waktu yang tersedia X Cycle Time }} \times 100
$$

c. Quality rate merupakan suatu rasio yang menggambarkan kemampuan peralatan dalam menghasilkan produk yang sesuai dengan standar yang telah ditetapkan oleh perusahaan. Quality dalam OEE dapat disebut juga jumlah unit produk baik yang berhasil diproduksi dibanding dengan total jumlah unit produk yang dihasilkan. Adapun rumus untuk menghitung nilai quality adalah:

$$
\frac{\text { Kapasitas Produksi-Deffect }}{\text { Kapasitas Produksi }} \times 100 \%
$$

Adapun batasan penentuan nilai-nilai OEE yang ideal terhadap pengukuran untuk perusahaan manufaktur dapat dilihat pada Tabel 1.

Tabel 1 Nilai Ideal Perhitungan OEE

\begin{tabular}{ll}
\hline Deskripsi & Nilai \\
\hline Availability & $>90 \%$ \\
Performance & $>95 \%$ \\
Quality & $>99 \%$ \\
OEE & $>85 \%$ \\
\hline
\end{tabular}


Adapun penjelasan dari nilai-nilai standar benchmark world class yang dianjurkan JIPM (Japan Institute of Plant Maintenance) adalah sebagai berikut:

a. Jika $\mathrm{OEE}=100 \%$, produksi dianggap sempurna: hanya memproduksi produk tanpa cacat, bekerja dalam performance yang cepat, dan tidak ada downtime.

b. Jika OEE $=85 \%$, produksi dianggap kelas dunia. Bagi banyak perusahaan, skor ini merupakan skor yang cocok untuk dijadikan goal jangka panjang.

c. Jika OEE $=60 \%$, produksi dianggap wajar, tapi menunjukkan ada ruang yang besar untuk improvement.

d. Jika OEE $=40 \%$, produksi dianggap memiliki skor yang rendah, tapi dalam kebanyakan kasus dapat dengan mudah diimprove melalui pengukuran langsung (misalnya dengan menelusuri alasan-alasan downtime dan menangani sumber-sumber penyebab downtime secara satu per satu).

\section{HASIL DAN PEMBAHASAN}

Gas Turbine Generator merupakan salah satu unit pembangkit listrik yang dimanfaatkan untuk menunjang proses produksi pupuk. Alat yang memanfaatkan gas sebagai fluida untuk memutar turbin dengan pembakaran internal sehingga dapat memutar generator lalu menghasilkan listrik. Di dalam turbin gas, energi kinetik dikonversikan menjadi energi mekanik melalui udara bertekanan yang memutar roda turbin sehingga menghasilkan daya. Sistem turbin gas yang paling sederhana terdiri dari tiga komponen yaitu kompresor ruang bakar dan turbin gas.Udara masuk kedalam kompresor melalui saluran masuk udara. Kompresor berfungsi untuk menghisap dan menaikkan tekanan udara tersebut, sehingga temperatur udara juga masuk kedalam ruang bakar. Didalam ruang bakar dilakukan proses pembakaran dengan cara mencampurkan udara bertekanan dan bahan bakar. Proses pembakaran tersebut dialirkan ke turbin gas melalui suatu nozel yang berfungsi untuk mengarahkan aliran tersebut ke turbin. Daya yang dihasilkan oleh turbin gas tersebut digunakan untuk memutar kompresornya.

Dalam proses kerjanya Gas Turbine Generator juga mengalami kendala kondisi peralatan sehingga tidak mampu bekerja secara maksimal.Berdasarkan hasil perhitungan Availability Rate untuk pada mesin gas turbin generator dapat dilihat pada Tabel 2. Selama 4 bulan penelitian diperoleh nilai availability yang cukup baik kecuali pada bulan Maret 2017 yang mengalami downtime selama 0,44 jam. Secara keseluruhan jika dibandingkan dengan standar availability menunjukkan bahwa Gas Turbine Generator masih mempunyai nilai availability yang cukup baik.

Tabel 2 Hasil perhitungan Availability

\begin{tabular}{llll}
\hline Bulan & $\begin{array}{l}\text { Loading } \\
\text { Time }\end{array}$ & $\begin{array}{l}\text { Total } \\
\text { Down } \\
\text { Time }\end{array}$ & Availability \\
\hline januari & 31,00 & 0,00 & $100 \%$ \\
Februari & 28,00 & 0,00 & $100 \%$ \\
Maret & 30,56 & 0,44 & $98,56 \%$ \\
April & 30,00 & 0,00 & $100 \%$ \\
\hline
\end{tabular}

Berdasarkan hasil Performance efficiency pada mesin gas turbin generator diperoleh nilai diantara $67 \%$ sampai $70 \%$ (Tabel 3). Nilai ini masih jauh dari standar $>95 \%$.

Tabel 3 Hasil perhitungan Performance efficiency

\begin{tabular}{llll} 
Bulan & $\begin{array}{l}\text { Total } \\
\text { Produksi }\end{array}$ & $\begin{array}{l}\text { Operating } \\
\text { Time }\end{array}$ & $\begin{array}{l}\text { Performance } \\
\text { Efficiency }\end{array}$ \\
\hline Januari & 85,405 & 126,335 & $67,60 \%$ \\
Februari & 77,14 & 114,920 & $67,12 \%$ \\
Maret & 85,405 & 122,920 & $69,48 \%$ \\
April & 82,65 & 117,941 & $70,07 \%$ \\
\hline
\end{tabular}

Adapun hasil perhitungan Quality Rate pada mesin gas turbine generator dapat dilihat pada Tabel 4 yang menunjukkan nilai $100 \%$. Nilai ini disebabkan mesin gas turbine generator hanya sebagai penunjang proses sehingga tidak terlalu banyak mempengaruhi kualitas produksi.

Tabel 4 Hasil perhitungan Quality Rate

\begin{tabular}{llll}
\hline Bulan & $\begin{array}{l}\text { Total net } \\
\text { produksi }\end{array}$ & $\begin{array}{l}\text { Defect } \\
\text { amount }\end{array}$ & $\begin{array}{l}\text { Quality } \\
\text { Rate }\end{array}$ \\
\hline Januari & 6,371 & 0,00 & $100 \%$ \\
Februari & 5,993 & 0,00 & $100 \%$ \\
Maret & 6,332 & 0,00 & $100 \%$ \\
April & 5,972 & 0,00 & $100 \%$ \\
\hline
\end{tabular}

Jika nilai availability, performance dan quality telah didapatkan, maka langkah selanjutnya yaitu melakukan perhitungan OEE. Adapun hasil perhitungan Overall Equipment Effectiveness pada mesin gas turbin generator dapat dilihat pada Tabel 5:

Gas Turbin Generator adapun nilai Availability rate selama 4 bulan yaitu sejak januari sampai april adalah sebesar 100\%, 
$100 \%, 98,56 \%$, dan $100 \%$. Hal ini menunjukkan bahwa nilai Availability rate telah memenuhi standar. Adapun nilai performance rate adalah sebesar $67,60 \%, 67,12 \%, 69,48 \%$ dan $70,07 \%$. Hal ini menunjukkan bahwa nilai Performance rate telah memenuhi standar. Adapun nilai quality rate adalah sebesar $100 \%$. Hal ini menunjukkan bahwa nilai Quality rate telah memenuhi standar.Adapun nilai efektifitas Overall Equipment Effectiveness (OEE) tertinggi adalah pada bulan April sebesar 70,07\% dan yang terendah pada bulan Februari sebesar $67,12 \%$ dengan nilai rata-rata OEE adalah sebesar $68,39 \%$.

Tabel 5 Hasil perhitungan Overall Equipment Effectiveness (85\%) gas turbine generator.

\begin{tabular}{lcccl}
\hline Bulan & AV & PE & RQ & OEE \\
\hline Januari & $100 \%$ & $67,60 \%$ & $100 \%$ & $67,60 \%$ \\
Februari & $100 \%$ & $67,60 \%$ & $100 \%$ & $67,12 \%$ \\
Maret & $98,56 \%$ & $69,48 \%$ & $100 \%$ & $68,47 \%$ \\
April & $100 \%$ & $70,07 \%$ & $100 \%$ & $70,07 \%$ \\
\hline \multicolumn{1}{c}{ OEE } & & & & $68,39 \%$ \\
\hline
\end{tabular}

Berdasarkan nilai OEE yang diperoleh secara keseluruhan masih dibawah standar yang ditetapkan Japan Institute of Plant Maintenance yaitu sebesar $85 \%$. Tidak tercapainya nilai tersebut lebih banyak disebabkan faktor performance efficiency yang tidak sesuai target. Hal ini sesuai dengan penelitian yang dilakukan (Chand \& Shirvani, 2000; Sharma \& Trikha, 2011; Singh, Gohil, Shah, \& Desai, 2013) bahwa performance efficiency mempunyai nilai yang paling rendah dibandingkan dengan parameter lain.

\section{KESIMPULAN}

Berdasarkan dari hasil analisis yang telah dilakukan diperoleh hasil bahwa dapat disimpulkan bahwa nilai OEE pada Gas Turbine Generator adalah 68,39\%. Nilai ini masih dibawah standar Japan Institute of Plant Maintenance sebesar $85 \%$. Pencapaian nilai ini lebih banyak disebabkan rendahnya performance efficiency yang dicapai. Penelitian ini dapat dilanjutkan dengan analisis penyebab tidak tercapainya nilai performance efficiency dan melakukan improvement untuk meningkatkan nilai OEE secara keseluruhan.

\section{UCAPAN TERIMAKASIH}

Ucapan terimakasih diberikan Jurusan Teknik Industri Universitas Malikussaleh dan semua pihak yang telah berkontribusi dalam penulisan artikel ini.

\section{DAFTAR PUSTAKA}

Chand, G., \& Shirvani, B. (2000). Implementation of TPM in cellular manufacture. Journal of Materials Processing Technology, 103(1), 149-154.

Garza-Reyes, J. A. (2015). From measuring overall equipment effectiveness (OEE) to overall resource effectiveness (ORE). Journal of Quality in Maintenance Engineering, 21(4), 506-527.

Gupta, A. K., \& Garg, R. K. (2012). OEE improvement by TPM implementation: a case study. International Journal of $I T$, Engineering and Applied Sciences Research, 1(1), 115-124.

Iswardi, I., \& Sayuti, M. (2016). Analisis Produktivitas Perawatan Mesin dengan Metode TPM (Total Productive Maintenance) Pada Mesin Mixing Section. Malikussaleh Journal of Mechanical Science and Technology, 4(2), 26-29.

Jannah, R. M., Supriyadi, S., \& Nalhadi, A. (2017). Analisis Efektivitas pada Mesin Centrifugal dengan Menggunakan Metode Overall Equipment Effectiveness (OEE). In Prosiding Seminar Nasional Riset Terapan/ SENASSET (pp. 170-175).

Jonsson, P., \& Lesshammar, M. (1999). Evaluation and Improvement of Manufacturing Performance Measurement Systems - The Role of OEE". International Journal of Operations and Production Management, 19, 15.

Nakajima, S. (1988). Introduction to Total Productive Maintenance. Portland: Productivity Press Inc.

R.Almeanazel, O. T. (2010). Total Productive Maintenance Review and Overall Equipment. Jordan Journal of Mechanical and Industrial Engineering, 4(4), 517-522.

Sharma, R., \& Trikha, V. (2011). TPM Implementation inPiston Manufacturing Industry for OEE. Current Trends in Engineering Research Vol, 1(1), 115-124.

Singh, R., Gohil, A. M., Shah, D. B., \& Desai, S. (2013). Total productive maintenance (TPM) implementation in a machine shop: A case study. Procedia Engineering, 51, 592599.

Singh, R., Shah, D. B., Gohil, A. M., \& Shah, M. H. (2013). Overall equipment effectiveness (OEE) calculation - Automation through hardware \& software development. Procedia Engineering, 51, 579-584. 